\title{
Comparative examination of Teachers' educational role and method in the Teaching-Learning process from the perspective of John Dewey and Abu Ali Sina
}

\author{
Jamalahdin Mostafa ${ }^{1, *}$, Faranak Ghodsi ${ }^{2}$, Rezvan Momenzadeh ${ }^{3}$ \\ ${ }^{1} \mathrm{MA}$ in History and Philosophy of Education (Islamic Education), Secretary of Education \\ Diwandareh City, Kurdistan, Iran \\ ${ }^{2} \mathrm{PhD}$ in Social Psychology. Faculty Member, Farhangyan University, Bent al-Hoda Sadr Pardis, \\ Sanandaj, Iran
}

${ }^{3} \mathrm{BS}$ in Guidance and Consulting, and Secretary of Education Diwandareh City, Kurdistan, Iran E-mail address: jamal.hija@gmail.com

Keywords: Dewey and Sina, Role and mythology, Teaching, Learning, Teacher.

\begin{abstract}
The Teaching-Learning process is a complex, widespread and time consuming task. To this end, the first step is to determine objectives we intend to reach and reaching these objectives necessitates using methods. Awareness of methodologies and objectives in the teaching process and specifically the educational role and method of teacher in the Teaching-Learning process requires understanding the opinions of renowned instructors and philosophers and scholars. Hence, the aim of the present research was to investigate the Teachers' educational role and methodologies in the Teaching-Learning process from the perspective of John Dewey and Abu Ali Sina. Here, in this research, first the educational role of the teacher in the Teaching-Learning process is expressed from the view of John Dewey and Abu Ali Sina and then, the educational objectives and methodologies of these two philosophers are put into discussion. The Dewey and Sina's educational objectives from the view of the teacher and its impacts on the society and the people under instruction have been examined. Later, by investigating similarities and differences of objectives and methods of the teachers' roles in the Teaching-Learning process by Dewey and Sina, we conclude that both philosophers consider the most significant and primary objectives of the teachers' educational role in the process of teaching as observing individual differences, group training and teaching based on tendencies and talents and interests of students. Meantime, these are the most important goals of the teachers in the Teaching-Learning process which these two philosophers share.
\end{abstract}

\section{INTRODUCTION}

In the human civilization, the goal of the teacher is teaching and learning assumes importance; for instance, educational schools, philosophers and educational scholars have discussed the objectives and goals of the teacher's role as this: Khawje Nasir Al Toosi considers the main goal and role of teaching and education as exploration of the nature and the universe and has also had more inclinations towards worldly and scientific issues. The said Khwaje thought of the major goal as moderation among the triad human powers (erotic, wrath based and speaking). He also paid more attention to the personal nature and ordered the instructors to using the theory of habits. In the Existentialism school, Marx believed that free choice (awareness intensity) of thee student is the foundation for teaching and hence he is responsible for his own choices (ShoariNejad, 2005). In the Idealists' school, Plato argued that the role and method of the teacher is to develop and cause to evolve Mind-Reminiscence of ideas and their application. In the Realist's school, Aristotle maintained that the educational role and method of the teacher to get the students to a perception and understanding through sensual perceptions as a result of teaching and learning is a natural act than artificial (ShoariNejad, 2005). According to the Islamic education, the major educational role and methodology of teacher in the Teaching-Learning process is to reach happiness. 
Now that the position and importance of the teachers' role in the Teaching-Learning process has been construed among philosophers and educational scholars, in accordance with the title of the research, it is recommended this subject matter be investigated from the view of two salient philosophers and thinkers, i.e. Abu Ali Sina and Dewey who respectively represent the Pragmatism and Islamic Masha so that some brief answers are provided for the research questions. For Dewey, the teacher is the support basis and a navigator not an authoritative dominant. Hoe role is to guide students who need consultation or assistance and thus a director emerges out of the problem solution bottom. Hence, he is considered to be the most renowned American genus. Another factor which brought him fame was the establishment of "School of Laboratory". He animated that "Freedom and Democracy" require an open class space and a kind of educational attitude which acquires the experimental -based research applicability in order for investigation and testing of values and beliefs.

A scholar came to prominence in the $4^{\text {th }}$ century, A.H. who was renowned in his times and was quite proficient in such sciences as Logic, Philosophy, and Medicine. Abu Ali Sina, known as Sheikh Al- Raees is a Masha Philosopher and famed physician of Iran and the World of Islam. His most important philosophical works are: Healing, Survival, Reference, Awareness and Tadabir AlManzel, literally meaning as Measures for the Houses. The major Abu Ali Sana's role is the expression of his own innovative philosophy which is Aristotle-based philosophy with Platocentered themes which is often influenced by Flotin and Proclus. Besides this impacts, another role of his is efforts and endeavor for regulating three thinking processes, i.e. Aristotle Masha Philosophy, Islamic World Outlook, and Neo-Plato World outlook, In this strife, by following the so-called Second Teacher "Farabi" he attempted to unite philosophy and religion (A'rafi, 2001).

Statement of the problem

To act towards the risky task of Education, it is imperative to have knowledge of basics, methodologies and its objectives and awareness of these instances won't occur unless by investigating and comparing the opinions of philosophers and thinkers of the Great Education Schools. Also, it seems that in the realm of the education, one can utilize the opinions and views of all educational instructors while determining an educational philosophy. It is of high importance that we need to use them for solving the problems governing the society and the educational system. To get familiar with the Dewey's and Sina's thoughts in the area of teachers' role and methodology in the Teaching-Learning process against the instructed person, we refer to instances so that we provide answers, though concise for one of the most underlying educational issues, i.e. shortage of theorizing. Focus on individual differences in form of group education for nurturing the morale of fact-finding and attainment of the human being to privilege and wisdom mentioned in the opinions and attitudes of these two philosophers from the West and Islam (Dewey and Sina), could be perhaps one of the major methodologies for resolving this problem. The primary issue intended in this research is the comparison of philosophical theories in the area of education and educational and teaching role and methodology and particularly investigating the special points to which both philosophers have focused attention with the Teaching-Learning process.

Significance of the research

Awareness of education methodologies and objectives, specifically the teachers' educational role and methodology requires understanding the opinions of Great instructors and philosophers of the education and anytime we desire to deal and analyze the theories of these philosophers in the area off education, such an immense task should be performed that might involve the risk of reduced depth of the research content. Therefore, here in this research, while referring to reasons, we narrow down our theme to investigating teachers; roles amid the educational goals from the view of these two philosophers, i.e. John Dewey and Abu Sina so that ground is laid for more indepth analyses.

Reasons

1. The Iranian Education has always been struggling with one of its most underlying problems, i.e. shortage of theorizing, thus we may attain new theorization. 
2. Focus on the point that theorization can be inspiring and may open the way for finding responses for education affairs is another reason.

3. Ibn Sina is the most prominent Masha representative; his scope off activities is widespread and the impacts he has is more far-reaching compared to other Islamic philosophers.

4. For Dewey, education should not be imagined as a measure for the lives; rather education is itself a life. The education process has in fact no end on its horizon. The Dewey's goal was to convert philosophy into a science. "Bring no argument, think of solution" is the summary of ten Dewey' philosophical attitudes; practical philosophy for participation in chivalry affairs and large experiments.

5. The Ibn Sina's educational views has a great position in the area of Islamic area to the point where some argue that he is the first Muslim scholar who has stated about Education. Also, he has had a comprehensive look at the education and has compiled a book about education and its principles named Measures for the Houses (A'rafi, 2001).

6 . Focus on the significance of comparative studies also indicates the choice of this subject matter.

Benefits of comparative studies are:

a) Acquisition of skills and fast an exact transference of it and gaining a systemic attitude along with an influential and all-out prudence

b) Comparative studies takes the researchers to the beyond of exclusivity and provides the possibility of knowledge over latent dimensions of the research subject matter, thus opening the way for some issues and disorders. The intellectual significance and role of comparative studies could also be obtained from the holy Koran. One of the Koranic methodologies is to create insight transformation and grant an influential wisdom over exposing people to comparison. Knowledgegenerating inference does possess such a concept.

\section{METHODOLOGY}

The methodology in this research is a qualitative research which falls under the comparative studies. A qualitative research is the one that emphasizes on holistic and qualitative information and using hermeneutic approaches. Its measurement methods lead more to description and interpretation than a statistical analysis. The goal of a qualitative research is the individual's perception or occurrence within its natural conditions and in accordance with the relevant context. The research is wholly about values. From among the various research methodologies of the qualitative research which are context finding, experimental, historic and descriptive and comparative, we choose the comparative investigation to examine and juxtapose objectives, and educational role and methods of the teacher within the Teaching-Learning process through the two said philosophers. A comparative method means understanding a phenomenon or view in the light of comparison; which is to say description and explanation of for and against positions.

Research scope

Teachers' objectives, methodologies and role in the Teaching-Learning process are based on the Ibn Sina and Dewey's views so that by using this comparison, special characteristics of educational theories of either the said philosophers begin to been known with regards to objectives, methodologies and roles of the teachers in the Teaching-Learning process.

\section{Statistical population}

This research, because it is not a field survey, no statistics and numbers are provided which means we are not dealing with a statistical population, rather we have a contextual population which contains some printed works about Dewey's and Ibn Sina's Educational Theories.

\section{Research instruments}

This research, because it is not a field survey, no questionnaire or interview are used; however, library note taking has been used in form of traditional and digital styles.

Research procedures

The research procedure is comparative upon which general principles an concepts and objectives, teachers' roles and methods are first investigated from the view of Dewey and Ibn Sina's views 
distinctly and thereafter, the positions of the said two scholars are compared so that responses are provided for the research questions.

Data analysis procedure

Given the fact that data analysis is performed in two quantitative and qualitative forms, but since the quantitative method is not applicable for the data analysis of this research, we turn to using the qualitative methods which includes rational, inferential and inquisitive analyses.

\section{FINDINGS}

1. What is the significance of the teachers' role and methodology in the Teaching-Learning process from the view of Dewey?

The fact the teacher has role to rebuild and produce knowledge within the teaching process and is regarded as a facilitator and guide of resources of knowledge (Husseini, 1951) assumes importance. Dewey states if exact attention is considered in educating the teacher and active method are applied in educating the instructors, in this case a teacher grows that has a high power of perception and understanding for addressing the knowledge of his students. For Dewey, philosophy and education are deeply interdependent, such that he considers education as a laboratory of philosophy. Philosophy being practical is an affair which has been over and over stressed and it is because of this that he argues : " Education should seek to actualize personality and create rational and moral preparation in the person for membership in a democratic society". Like Durkheim, John Dewey considered education as a social category which is indispensable from politics. Educating people is significant in order that they become members to a democratic society as citizens. However, this is only one side of the coin, because a democratic society needs such citizens for its own survival. In other words, a democratic state requires education more than any other state and needless to say that getting people engaged in the governance is directly correlated with education and raising of the citizens' awareness level. Democratic societies by eliminating indecent social limitations and constraints seek to expand popular scope of activities, paving numerous opportunities for the fulfillment of talents and their growth and such groundwork is accompanied by educational growth and development.

The movement of the education in a democratic society is aimed at creating mutual understanding between national elements and global elements. Children become acquainted with the consequences of the disagreements between states and wars occurred through education and it is attempted that children are shown the current civilization is a result of cooperation and participation by numerous international states other than destructive wars. Thus, we find that Dewey argues that the teacher's role serves as a patient and supportive facilitator and a guiding non-inculcating person to the student with no power who merely acts based on the child's experiences and is wholly an indirect controller about observations, experiments and rationality of the children (Shariatmadari, 2011). He considers freedom as a means in the direction of activity and reaching a problem solution. In the process of engagement in discovery and problem solution by the student, as per Dewey, the teacher focuses attention to their individual differences and their extent of abilities and competencies, while establishing bilateral communication between the teacher and learner in a group form.

2. What is the significance of teachers' role and methodology in the Teaching-Learning process from the view of Ibn Sina?

In expressing the characteristic of a teacher, and given his role and risky responsibility in forming the human dignity, Ibn Sina asks fathers to firstly take care while choosing an instructor to be prudent and religious and to identify the path of morality edification and child raising. He should be dignified, humane and caring, chaste and pious and knows the companionship path and later Ibn Sina refers to acquaintance to how to raise the child. A variety of above characteristics indicates that Abu Ali Sina values the high position of thee teacher within the Teaching-Learning system. He states teacher is the behavioral pattern of children and they copy his conducts and thus actualize them in their lives. Therefore, he states the teacher prior to transferring knowledge and truths to students must get them aware of his own beliefs and values as well as etiquettes and privileges granted to him. In a paper about the educational perspective by Ibn Sina, the UNESCO writes: Ibn 
Sina construes the significance of choosing a teacher and decorating him with some theoretical and moral education which is something more than provision of information, because students acquire numerous values and beliefs from their own teachers. Hence, while expressing the importance of teachers' role and methodologies, in Sina's view, it is imperative to choose a teacher from among the best of people with regards to some religious and moral positive patterns so that he can teach the students education objectives like faith, decent morality and good habits, well-being, literacy and profession.

3. What are the objectives of the teachers' role and methodology in the Teaching-Learning process from the view of Dewey?

For Dewey, the end objectives of Education lie inside it. The Education end in the first step is the expansion of critical thinking styles. In the end, education should be accompanied by actualization of personality and creation of rational and moral preparation in the person for membership in a democratic society. Therefore, Dewey considers the objectives of the teacher like other various human objectives which are performed through life democratic ways. Thus, the teachers' objectives in the Teaching -Learning process should not arise from objectives which are imposed on the student from outside rather they should be founded upon wants, needs and original internal shortages which contain acquired habits. On the same basis, the teachers' objectives should be to convert either students to an active project through empirical education or learning in practice. Put it simply, education has no objective but to make person willing to continue his education. In other words, learning has no end but to continue learning and this is only possible in a democratic society which prevents the emergence of disagreements and class, ethnic and racial segregation in the present and the future.

4. What are the objectives of role and methodology of the teacher in the Teaching-Learning process from the view of Ibn Sina?

For Ibn Sina, happiness is the highest stage of the human want. Therefore, any sort of attempt on the part of the teacher within the Teaching-earning process should be aimed at so-called Closeness to God, leading to real blessing.

5. What are the teachers' teaching methodologies with the Teaching-earning process from the perspective of Dewey?

In the teaching methodology process, Dewey asks teachers to conduct the tricky task of "expressing the subject empirically" while demanding them to create an environment wherein the current children activities are faced with problematic situations in which necessary knowledge, science skills, history and art are applied for eliminating these problems. He points out that: teachers must have the ability to see the world in the way children and adults see it. According to the Dewey's educational rationale educating is performed through practice and for living. The teacher's method in this respect is to navigate the learner towards research by means of research and for research and the conduct of the research act consists of the following stages:

1. Feeling off need which arises from exposing to new situations and disturbance of balance.

2. Problem analysis, i.e. investigating and discovery of dimensions and in fact definition of problem aspects.

3. Recommendations of various solutions.

4. Testing of various solutions by students until one of them is accepted by the mind.

5. Action which is the final touchstone of the recommended solutions and must be substantiated by a scientific way.

To Dewey, the presence of the teacher at school is not for imposing definite ideas or creating specific habits in the child; rather teacher's presence as a member of the community is to help the child choose the experiences and aids him respond appropriately. Dewey claims knowledge results from the effects of natural objects on us; therefore, the teacher's methodology should be to provide the ground for using objects so that necessary knowledge is obtained along the students' activities, thus making him be an active researcher. In connection with the student and his educational method, Dewey states: there must be a reciprocal cooperation and relationship between the students themselves and the teacher and tasks should be executed collectively in students-centered forms and 
active school settings. As per Dewey's view, assistance is the foundation for the transformation of a number of educational patterns. In this respect, students learn through cooperation and participation in a group form and thee Teaching-earning character base on assistance and cooperation are: 1 . Positive solidarity, 2. Individual accountability, 3. Face to face interaction, 4. Social skills and 5. Group processing.

6. What are the teachers' teaching, methods in the Teaching-Learning process from the perspective of Ibn Sina?

The purpose is all activities and measures which are provided by the teacher for managing Teaching-Learning process so that this process is rapidly and quickly conducted. TeachingLearning methodologies are varied and teaching each of the science areas must be proportionate to the nature of the science. Ibn Sina argues that which the child demands and is inclined towards it is not possible for him; rather he should be taught about contents in line with attention to individual differences, preferably collectively which is commensurate with his taste and understanding. He also maintains everyone is interested in some knowledge or technique. Therefore, the people charged with education are obligated to first measure their talents ad capabilities, then to teach them appropriate and useful bodies of knowledge (Ebrahim Zade, 2012). Ibn Sina advises music and sports and playing methods for purification of feelings and preparation of later stages for the children fewer than 6 years of age (Riazi, 2008).

By way of inculcation when the child is ready for learning from 6 to 14 years of age, he must be taught first and foremost the holy Koran and Struggle in the path of God and then, alphabetics (Riazi, 2008). Thus, we need to further the children awareness by educating them to memorize poems with the essence of science and hospitality and decent acts and goodness to parents in rejection of indecency and ignorance and thereafter by educating science and knowledge and also teaching them by the age of 14 some techniques which are appropriate to their talents and nature (ShoariNejad, 2005).

In the book, Measures for the Houses, Ibn Sina also refers to the method of advice and exhortation which should be done along with prudence accompanied by softness and leniency and in privacy. He argues that good habits should be taught to the child prior to the appearance of indecent habits and if necessary, the child should be treated with mild punishment by way of rebuke (ShoariNejad, 2005).

7. What similarities are there between objectives and methods of teachers' role within ten TeachingLearning in regard to the Dewey's opinions and those of Ibn Sina?

-While discussing objectives, both philosophers emphasize on education as a process which affects our internal essence such that its role in life could be evident in our daily life;

- While discussing ways, both philosophers place emphasis on collective education;

- While discussing methodologies, both philosophers, both philosophers stress the necessity of attention to individual differences within the Teaching-Learning process by the teacher;

-While discussing methodologies, both philosophers argue that teaching must be proportionate to the conditions and talents of the students;

- While discussing objectives, Ibn Sina is similar to the Dewey's view in speaking of teaching and applying instruments which are intended for each industry;

- Both philosophers ask instructions to eliminate learning problems through art.

8. What are the differences between teacher's role objectives and methodologies within the Teaching-Learning process in Dewey's and Ibn Sina's views?

- Dewey argues that the students should attempts to resolve problems which are accepted by his mindset through testing and trials without the need for he feels in discovery of the causes of issues and the unknown. However, Ibn Sina, while discussing punitive education asks the teacher to highest his student aware of secrets and causes and daily events he sees and gets through the cause of the crash of objects or blinking of stars.

- In imitation education, Ibn Sina requires students to accept the words of their teacher without proof and immediately, where this perspective differs from that of Dewey who states the presence of the teacher at school is not for imposing certain ideas or specific habits; rather the teacher is a 
mere guide for the discovery of the questions arising from the experiences as inferred by the child in connection with his surroundings. It appears the learning method in the Dewey is problem oriented wherein the learners will be helped to learn through inquire, being different with the view of Ibn Sina's attitudes on imposition of ideas on the student.

-Speaking generally and expressing contents in an abstract way in then Ibn Sina's school seems to be mismatch with the Dewey's school who values thoughts obsession and discovery based on processes, stating the basis of the issue and the way to deal it and the away for reaching the answer.

- For Ibn Sina, the child must be taught Koran, Principles, Religious Obligations, Arabic language and the science of Words and terminologies; however, Dewey seems to be overlooking this.

Table 1. Dewey and Ibn Sina's similarities in teachers' role and educational methodology

\begin{tabular}{|c|}
\hline Dewey and Ibn Sina's similarities in teachers' role and educational methodology \\
\hline Emphasis on group training \\
\hline Attention to the scientific freedom as an educational instrument \\
\hline Attention to the principle of observing individual differences \\
\hline Focus on talents and tendencies of the students while teaching \\
\hline Focus o using technical instruments in difference professions \\
\hline
\end{tabular}

Table2. Dewey and Ibn Sina's differences in teachers' role and educational methodology

\begin{tabular}{|c|}
\hline Dewey and Ibn Sina's differences in teachers' role and educational methodology \\
\hline Teacher-orientedness in the Ibn Sina's school against student-orientedness of John Dewey \\
\hline $\begin{array}{c}\text { Dewey stresses more on using investigation and cooperation in creating, resolving, and discovery of } \\
\text { answers to questions by the students themselves against inculcation of the information by the teacher } \\
\text { and emphasis on scientific memoir by Ibn Sina }\end{array}$ \\
\hline $\begin{array}{c}\text { In Dewey's school, teacher and students are both learners, however in Ibn Sin's school of thought the } \\
\text { teacher is the one that teaches and the learner is the one that learns }\end{array}$ \\
\hline $\begin{array}{c}\text { Spiritual happiness of the student is in Closeness to God as the need of education from the view of Ibn } \\
\text { Sina against becoming researchers in the Dewey's teaching }\end{array}$ \\
\hline
\end{tabular}

\section{CONCLUSION}

The Dewey's educational end objectives within the Teaching-Learning process is to build a productive and industrious society and researcher humans in the laboratory of the world surrounding and inside a society as a whole and a society which is always lives through a shadow of equations and puzzles. Finally the end goal is to build democratic citizens for avoiding discriminations and social differences and the role of the guiding teacher is to solve puzzles and issues which are created by the students. For Dewey, the teachers becomes aware of the abilities and interest of the students and directs them in the course of useful utilization of their inclinations and guides them through the freedom channel and scientific democracy with a test and error methodology. While discussing teachers' methodologies by Dewey within the Teaching-Learning process, the end is to make the earner be inclined towards group activities and to create a sense of need and problem solution and problem analysis and to face with scientific challenges as a whole. For Ibn Sin, happiness and Closeness to God is achieved by education of Koran and building of humans who are accustomed with moral values like goodness to parents and good deeds to the great and thus overcome laziness and laxity with resort to creating good habits during childhood. Bodily punishment and rebuke has not been rejected in Ibn Sina's school of thought for acquiring Islamic privileges and virtues. Attention to individual differences in collective education is advised and respect for the teachers has been obligated. Both philosophers focus attention to the group education which brings about competition along with friendship in the Teaching -Learning process. They have all stressed social values and etiquettes and considered education of techniques and special professions. In Ibn Sina's the rebuke of tee learner is seen while in the Dewey's view, no reference to punishment and rebuke is made. Dewey's methodologies is bilateral and contains practice method and optional learning, i.e. both students and the teacher are learners, hence for Ibn Sina learning is obligatory ad is unilateral on the part from teacher to the student. 


\section{References}

[1]. Ebrahim Zade, I. (2012). Education philosophy. Tehran: PNU Publication.

[2]. ShoariNejad, A. A. (2005). History and education philosophy. Tehran: Amir Kabir Publication.

[3]. Husseini, S. A. A. (1951), Creative thinking as the end objective of Education. Shiraz: Jungle publication.

[4]. A'rafi, A. R. (2001). Opinions of Muslim scholars in Education and its basics. Tehran: SAMT Publication.

[5]. Shariatmadari, A. (2011). Principles and philosophy of education. Tehran: Amir Kabir publication.

[6]. Riazi, A. M. (2008). English for the students majoring in History and Education Philosophy. Tehran: SAMT Publication. 